\title{
Alcoholic Beverages in Indonesian Movies
}

\author{
Redi Panuju and Daniel Susilo* \\ Faculty of Communications Science, Dr Soetomo University, Indonesia \\ Address correspondence to Daniel Susilo,daniel.susilo@unitomo.ac.id
}

Received 28 August 2018; Revised 08 November 2018; Accepted 14 November 2018

Copyright (C) 2018 Daniel Susilo, et al. This is an open access article distributed under the terms of the Creative Commons Attribution License, which permits unrestricted use, distribution, and reproduction in any medium, provided the original work is properly cited.

\begin{abstract}
Alcoholic beverages, or what is often referred to as liquor is a threat to people's lives due to destructive effects when consumed in excess. In Indonesia, the prohibition on using alcoholic beverages is regulated in Criminal Code (KUHP). Dealers who cause drunkenness and anyone who makes children under the age of 16 drunk are subject to prison sentences. However, as a life story, the phenomenon of using alcoholic beverages is fascinating and because of that, many works of art such as movies make use of the phenomenon of using alcoholic beverages as a story. This article tries to explain how liquor is taken to a big screen, both as a primary and complementary story. The data were obtained through observations of Indonesian movies containing liquor scenes in a period of 1970-1998 and after 2000. Meanwhile, the data analysis used narrative analysis.
\end{abstract}

Keywords: alcoholic beverages; indonesian movies; main stories; narrative analysis; supporting stories

\section{Introduction}

In the Encyclopaedia Britannica, on-line booze is called distilled spirit or liquor, which is a type of alcoholic beverage in the form of ethanol. It is made from grains or vegetables by fermentation; examples of liquor are wine, vodka, gin, tequila, rum, whiskey, brandy and soju. In Indonesia, the terms liquor and alcoholic beverages overlap, so between fermented and non-fermented drinks, both are considered liquor. Therefore, alcoholic beverages that are not distilled are also considered liquor, such as beer, tuak, wine and cider. Unlike those in North America and India, alcoholic beverages do not go through distillation with lower alcohol content.

Indonesian law prohibits alcohol from circulating freely in the community because it is feared that it will disturb order and security. For example, in Criminal Code (KUHP) article 300, it is stated that there is a ban for dealers who cause drunkenness. Also, anyone who causes children under the age of 16 to get drunk is threatened with imprisonment.
The State prohibition on free circulation of liquor is related to consequences of excessive consumption. Excessive consumption of liquor can lead to disruption of liver function, which can lead to hepatitis, gastric damage, damage to body tissues, increased risk of breast cancer, damage to brain function, and damage to the heart and kidneys. This could result in a stroke, nerve paralysis and organ failure, which could lead to disability and even damage to a fetus, and result in death [1].

In Indonesian society, alcoholic beverages with low alcohol content are part of the social tradition used for cohesiveness functions. In Tuban, East Java, it is a tradition of parties with alcoholic beverages whose ingredients are extracted from Aren trees, called Tuak. Before being fermented, tuak is sweet and is called Legen. While on the island of Bali, this Tuak drink is used in the tradition of Cockfighting, where people enjoy food made from chicken blood and drink tuak.

However, people often make their own liquor from ingredients that are not permitted for drinking. Examples include mixing spritus, kerosene and ethanol with unclear composition. Alcohol that is made carelessly is called "oplosan". This type of liquor often results in death for people who consume it. KOMPAS Daily [2] reported that in just one month (March 2018), the death toll from liquor in Indonesia reached 118 people. According to Deputy Chief of Police of the Republic of Indonesia, Commissioner General Syahfruddin, the incidence of deaths due to oplosan liquor occurred in West Java, DKI and South Kalimantan.

The phenomenon of using oplosan liquor occurs in all social statuses, ranging from economically weak to elite. A TV station reported that three TNI members were killed as a result of consuming alcoholic beverages made from wound healing alcohol [3]. 
What is its relationship with a movie? As stated by Redi Panuju [4], a movie, as a mass media has various functions. Mass media conveys information in the form of opinions and social facts; as such, mass media is considered a "reflector", as a mirror where the audience can see themselves. In addition to relaying a message has an imitation effect.

Ariel Haryanto [5] stated that as a social fact, movies are more serious than data such as scientific books, People's Consultative Assembly of Indonesia (MPR) decisions. Why? Because in movies, we can pay attention to people who make movies are big businessmen; the purpose would be to make a profit. Making a movie requires a lot of funds; it requires a large investment. Movies are not made for political purposes, but for money. Furthermore, filmmakers can only make money in a way that pleases people. Therefore, methodologically, a movie becomes interesting to note, because it is a crest or affirmation of what has become the norm in society. Moviemakers do not want to run the risk of making strange ones. Filmmakers only reiterated what the public believed. The movie does not always reflect reality, but clearly reaffirms norms that have become dominant.

A news report said that study was conducted on five thousand teenagers aged 15 years and over in the UK. One result is that these teenagers are most likely to try drinking alcoholic beverages or take part in a liquor party after watching a similar scene in a movie. A researcher from the School of Oral and Dental Sciences in Bristol, Andrea Waylen, said they took into account a number of factors related to teenagers and children who were the object of the research. The results of this study are in line with similar studies conducted in the United States and Europe. "Teenagers are encouraged by their curiosity to try alcoholic beverages after watching similar scenes in movies, especially scenes relating to a liquor party and alcohol-related problems," said Waylen, quoted from Reuter. Waylen analyzed long-term study data from children in Bristol. More than five thousand children were told to choose 50 popular movies they had watched randomly. Researchers then analyzed the alcohol use scene that appeared in each movie. The result? Teenagers who were least exposed to alcoholic beverages watched a similar scene for $27 \mathrm{~min}$ in total. The next highest group had seen 28-44 min, then 45-63 min and those exposed the highest to alcoholic beverages watched more than 63 minutes [6].

In movies, liquor is used as an interesting scene for the audience. Scenes or stories about liquor are used as story aligners, but many are also used as part of the main story (main plot). Outside of Indonesia can be found stories about liquor. Example: a film titled Beerfest (2006) which tells about two brothers traveling to Germany to carry out the tradition of hammering their grandfather's ashes into the sea, but on the way, they were secretly trapped in a beer drinking competition. In the film titled The
Adventures of Bob and Doug McKenzie: Strange Brew (1983), Starring Rick Morani and Dave Thomas, this Canadian release film tells of two unemployed brothers, Bob and Doug McKenzie, who tried to get free beer by squeezing a beer shop local by putting a mouse into a bottle. However, their actions actually caused them to get a job at a brewery. The next film titled Beer Wars (2009) is a documentary film that raises the story of resistance from independent beer companies in the land of Uncle Sam, who opposes policies of established industrial giants who are determined to put a small company out of the growing American business circle. Several additional movies exist about liquor, including Superbad 2007), Drinking Buddies (2013), National Lampoon's Animal House (1978), American Beer (2004), One Man Drinking a Glass of Beer (1897) and Fubar (2002). There is even a cartoon type film for kids that references alcohol as a life solution [7].

\section{How in Indonesia?}

The beginning of Indonesian movie history cannot be separated from social change in Indonesia. When the first cinema in Indonesia was established in Batavia, the capital of the colony, a new era had begun in Indonesia, the ethical age. This era is an era of expansion and prosperity of People's credit services, government pawnshops, information services, improvement of agriculture, opiumregie, health improvement, treatment for people, post services, telegram, telephone, state railroad and schools. The advertisement in Bintang Betawi [8] Daily about the screening of the first movie in Indonesia was obvious to bring in the spirit of this ethical era [9].

After the movie was shown in a cinema building, a cinema class and audience class group appeared. In the provincial capital, Jakarta, there is always a cinema theatre dedicated to European audiences, as well as to the lower middle class; there is also a special cinema relating to watching behavior. In class III cinemas for the lower middle class, viewers can watch movies while eating peanuts or sweet nutmeg [9]. It is very possible that Europeans like wine; they watch movies while carrying wine.

This article attempts to find and analyze liquor in Indonesian movies.

\section{Method}

This research is explorative and includes a search. Search for Indonesian movies that contain stories or scenes about liquor from 1970-2018. During these years, the background of authoritarian governance in the New Order era (1966-1998) tended to be authoritarian so that freedom of expression was limited and the period of reformation (1989-208) tended to be democratic; thus, the freedom of expression was guaranteed by human rights. This study uses a method of narrative analysis. According to Rachma Ida (2014: 147), the narrative analysis is used to understand or know how stories or 
storylines are made or structured. The analysis uses three concepts, namely story, plot and genre. Stories are chronological sequences of all events or meanings of events, while plots include anything explicitly indicated in the movie text or events physically shown. The genre refers to the type of movies, which is divided into action, horror, comedy and drama types.

After being observed through movie documents on YouTube, the title of the film contained scenes of consuming liquor from the drama genre (2 movies), action genre ( 9 movies) and the comedy genre ( 2 movies).

\section{Conceptual Structure}

Referring to the concept of "nation" from Ben Anderson [10], nation is a result of images carried out by members of the community and with that image, a nation forms its identity; the movie as a means of imagining something, can also be used by moviemakers to visualize and/or narrate oneself as a member of a nation's community. Sazkia Noor Anggraini [11] interpreted 'movie' as a form of cultural product that shaped the image of a nation and, at the same time, formed the imagination of a nation.

Therefore, creativity in making movies is always related with the situation in their time. As the results of Anggraini's research [11] above show, a movie is a strategic text in the upheaval and turmoil of the people in the colonial period, then in the era of national awakening to the beginning of independence. Movies such as Terang Boelan, Dasima, to Rentjong Atjeh made before independence, have shown the antithesis of colonialism. These movies emerged when the country was still colonized, but its formulas, forms and presentation could be seen as self-sufficient, though not entirely, by incorporating elements of hybridity that the public liked. The appeal of the movie at the time of national awakening was the inclusion of indigenous tastes in a movie which, at that time, was aimed at European market share. Music, clothing, lifestyle and a response from this film are not a single entity.

Previous research shows there are always compromises between movies as an expression of public opinion in time and the intent of moviemakers who carry a universal humanism mission. People hate colonialism, but not on music, clothing and lifestyle. Artists show their admiration for a culture [12,13].

Movies are also referred to as a representation system that can be a window to see the dynamics of people's lives in a certain period of time when a movie is made. A movie, according to Stuart Hall [14], is a representation system in which 'meaning' practices are carried out. Meanings are produced through language using codes or signs that symbolize or refer to objects, people, events or things that are considered of the "real world". Ratna Noviani [15] studied eight teenage movies produced from the 1970 s to 1980 s showing a shift in discourse about the dynamics of the teenage world, being increasingly complex from decade to decade. Discourse about teenagers who are considered good or naughty tends not to change from decade to decade. A good teenager is always smart, active and has achievements. However, naughty teenagers like to make problems both at home and at school, whether it is through smoking, getting drunk or fighting.

Creativity in making movies is determined by political situations and conditions at a particular time. Eka Nada Shofa Alkhajar's research [16] shows that there has been a link between the Indonesian movie crisis from 1957-1968 and 1992-2000 with the mentality of the nation. From this study, it is known that in the period 1957-1968, the stability and political constellation that existed also influenced the condition of movies in the country; in this time context, there was often a cabinet change that affected the government's concentration on a movie because it adopted a system known as liberal democracy (1950-1959), marked by parliamentary democracy. Then, there was friction between the power of the Pancasila and the communists in the world of film as an example of the existence of communist wing organizations, namely PAPFIAS, SARBUFIS, LEKRA and so on. In addition, imported movies previously intended to spur the development of Indonesian movies, by acting as executioners for national movies. This can be seen at least from 1948 to 1952, where imported movies ranged from 290 to 800 titles. Finally, national movie producers led by PPFI closed the movie studios, which marked the first movie crisis. From 1992-2000, several factors that caused the decline in productivity of the Indonesian movie industry were, first, the rapid advances in technology or the audiovisual industry, especially home entertainment (video cassettes, laser discs, video compact discs / VCDs, digital video discs / DVDs) as a spectacle media alternative; second, a flood of imported movies (third world countries as new markets); third, development of private TV stations (the era of film changed to home and booming of soap operas); fourth, relatively low movie quality (ideas do not develop, this is marked by a number of sex-related and reckless movies); fifth, changes in market demands (audience tastes, freedom of expression, age adjustment, etc.).

Without realizing it, movies often relate to ways of expressing racist and ideological tendencies [5]. Seeing life with certain black and white hatred and form stereotypes, Ariel Haryanto observed several movies that narrated the events of 1965 , which were told of or made after 1998. The movies included Puisi tak Terkuburkan (Garin Nugroho), Gie, Dancer and Surat dari Praha. The movie is about the same as the evil figure of Communists with misleading characteristics. These would include clever but cunning, innocent but ignorant and lost, bad lucky like marrying a leftist (communist ideology), a left government scholarship and a leftist art group. There is 


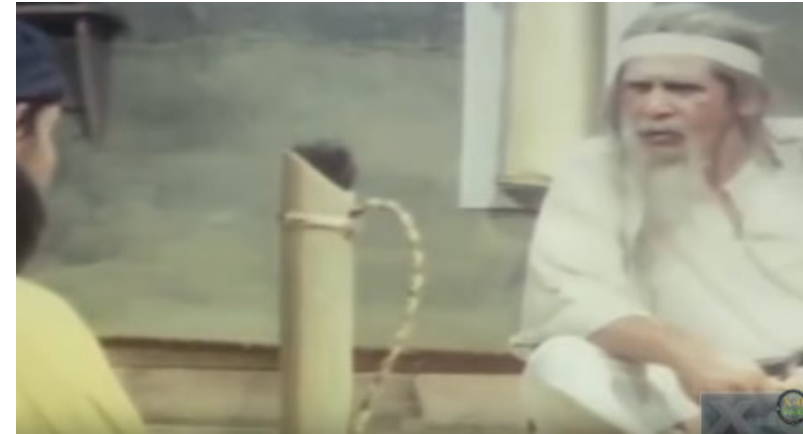

Figure 1: Bumbung, where Tuak is in the "Sengatan Satria Beracun" (1988) movie.

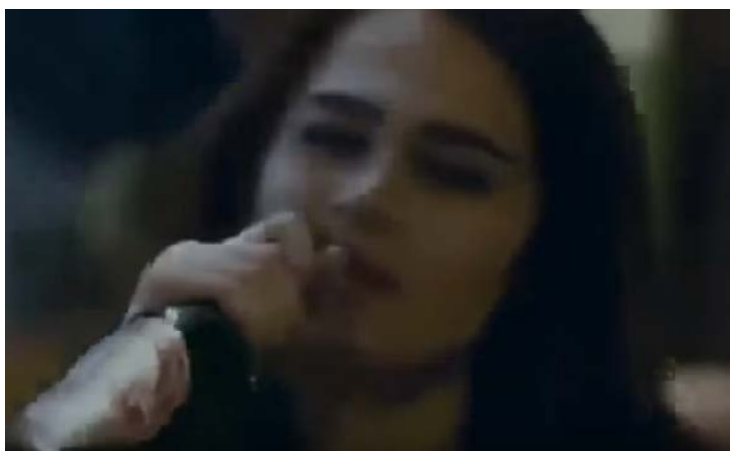

Figure 2: The scene of a teenager celebrating the Sweet Heart gang in a coffee shop.

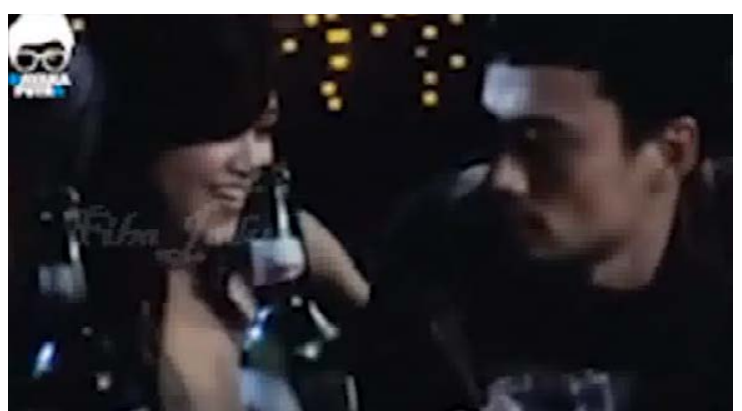

Figure 3: Scene sequel in Arwah Goyang Kerawang (2011) movie.

no story about people who are honest, kind and smart but have the ideology of Marxism.

From this conceptual structure, it can be said that a movie is an ideological expression that develops in its society and is formed based on certain representations.

In social reality, several stories relate to factors that encourage a person to consume alcohol. Karamoy (2004) revealed that there are two factors that primarily influence the behavior of alcoholic beverages, namely internal factors and external factors. These can be further subdivided to include family, living environment, group conformity, school conditions and education. Meanwhile, according to Hawari (2001), several factors influence a person to consume alcoholic beverages, including 1) Family factors: families are always the main suspects for alcohol abuse. The reason is, the family is most times, the closest environment that indirectly influences one's personality and behavior. 2) Personality factors: the personality of alcohol users also plays a role in this behavior. In teenagers, alcohol abuse usually has low self-concept and self-esteem. Emotional development is hampered by the marked inability of individuals to express their emotions naturally. They may become easily anxious, passive, aggressive and potentially depressed. 3) Factors of peer groups: groups or peers who use alcohol have a strong enough ability to influence people around them to use alcohol. 4) The factor of opportunity: the easier it is to obtain alcohol, arguably the trigger for the current rise of alcohol consumption [17].

Liquor is used in movies as an emphasis on social situations that are not normal and tend to be connoted as abnormal characteristics of life. Slamet Rahardjo, in his film Telegram, uses a liquor scene to reinforce the practice of prostitution. Usually, liquor is not alone but is combined with cigarettes, drugs and sexual diseases (Agung Cahyono, 2007) [18].

\section{Research Results and Discussion}

\subsection{Liquor as the main story in the movie}

Liquor is used in movies or movies for a number of reasons, namely as a representation of the situation, character characteristics and to show the social and cultural background of a community at a certain time. The consumption of liquor can be a central story that is attached to a character or just as a small part to show the detailed aspects of a message; in other words, something the moviemaker wants to highlight. In the Mandarin Movie Drunken Master (Jacky Chan), for example, liquor (tuak) becomes the main characteristic of warriors. The swordsman has not been able to do his ultimate martial art skills before drinking tuak. If one has swallowed tuak, let alone become drunk, then the opponent can be defeated easily.

Of the 11 movies observed, only one movie used tuak as a central story, namely Sengatan Satria Beracun (1988). The movie is based on the famous novel by Sabastian Tito entitled Wiro Sableng 212. This movie is included in the action genre because it visually speaks of the martial world; the social background is also about the martial world in the past from a place in Indonesia. Starring Devi Ipon and Tony Hidayad, it focuses on the figure of a teacher who likes to get drunk, so he is nicknamed Dewa Tuak (Tuak God); his student, Pengging (Robert Santoso) betrayed him and ran away. He brought his teacher's ancient book, where Dewa Tuak always carries tuak stored in bumbung (a place to drink made of bamboo trees). While Pengging likes cockfighting gambling, after the fight, Pengging killed the owner of the chicken who defeated him.

\subsection{Liquor as the Complementary Story}

In the movie, liquor is used as a complement to a story. The following descriptions are found from other titles: 


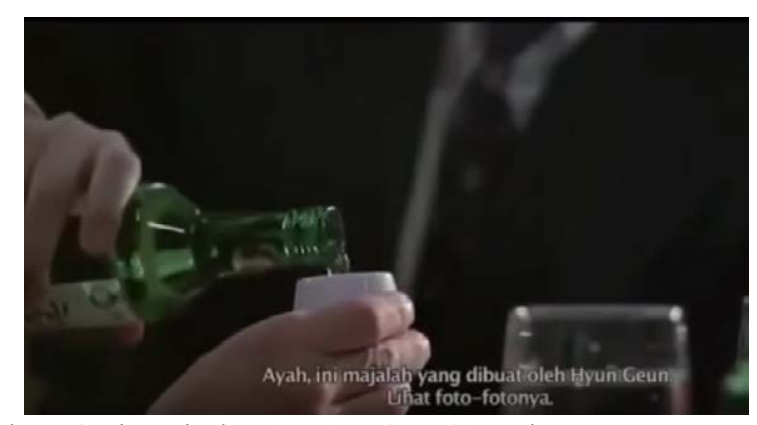

Figure 4: Liquor in the "Ayat Ayat Cinta 2" movie.

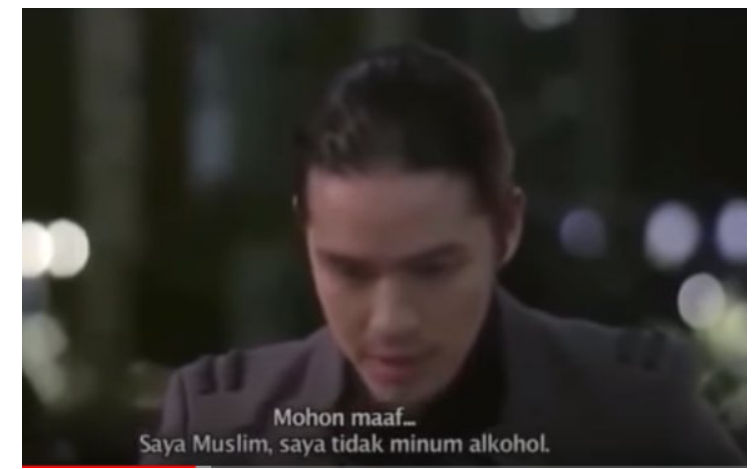

Figure 5: Text that shows negation of alcohol in the "Ayat Ayat Cinta 2" movie.

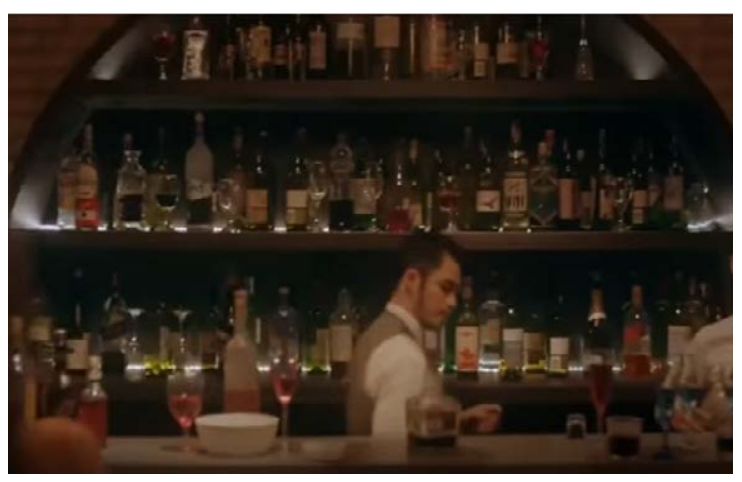

Figure 6: Liquor in the casino in the "Benyamin Biang Kerok" movie.

\subsection{Movies and Rebellion on Structure}

Indonesian movies in the 1970-1980s showed two different social realities. In the context of the use of liquor, the action genre movies that take place in the era of the kingdom (before Indonesian Independence), liquor is identical to the behavior of kompeni (Dutch colonizers), the representation of certain social classes of Kompeni employees from native people. Dutch and native accomplices were portrayed as arbitrarily against the people, confiscating the property of people who did not pay taxes, and like to rape girls. Liquor becomes a reinforcement that they are atheist and inhumane. Likewise, with Indonesian movies in the same year as the setting of the Kings' life of Java, the rebels (like Minak Jinggo) are portrayed as fierce, violent and harsh. His life is full of luxury, parties and liquor (see also Salesman, 2018) [19].

Action genre movies that take the past setting are interesting to analyze in terms of their social relevance.
During this time, the political situation in Indonesia was heading towards authoritarianism. The New Order government under the regime of President Soeharto was seeking political stability as a precondition for economic development. Therefore, at that time, development trilogy put the political stability jargon in the first place; after that economic growth, and then even distribution. Political stability is considered a priority, so freedom of speech, which contains criticism of the government, is considered a violation and can even be accused of subversive conduct. To carry out the authoritarianism ambition, the New Order government strengthened the military to carry out social functions, so that it was known as dual function ABRI (Indonesian Military Armed Forces). The military network is made from the centre to the regional regions, even to the village level, known as BABINSA (Village Development Board). Military apparatus that have the task of "silencing" social and political criticisms are called BAKORTANAS (National Defense Coordination Agency). While at the provincial level, it is called KAKORTANASDA (Regional National Defense Coordination Agency), (see also Nurrahmi, 2018) [20].

In the context of the movie, the government imposed very strict censorship through Movie Censorship Board (BSF), which was under the control of the Indonesian Information Department. This socio-political situation is what causes rarity of movies that take the place of the arbitrariness of the government at that time. Criticism was directed at Dutch colonizers and kings two hundred years earlier. Although finally, the 1980-1990 Indonesian movies tended to be imaginative, they did not raise the existing social reality, but the audience continued to like movies of that genre. At that time, famous movie stars were born, such as Advent Bangun, George Rudy, Zainal Abidin, Roy Marten, Robby Sugara, Inneke Koesherawati, Suzana, Yenny Rachman, Rano Karno Yessy Gusman, Yetty Octavia and so on.

Political criticism was filtered, but cigarettes, liquor, prostitution and free promiscuity were loosened into settings in Indonesian movies. Producers, scriptwriters, screenwriters and directors are subjects who are responsible for framing a movie. Panuju [21] states that framing is thought the concept, or ideology that is behind the media. The movie as a mass media cannot be separated from the interests of framing. Referring to Ariel Haryanto [5], the purpose of moviemakers (cinema) is none other than to obtain financial benefits that are as large as possible. Then, the movie is made to be watched. From the number of viewers who buy tickets at the cinema, it can be seen how many people bought the movie product. The moviemaker should not get away from his social reality when making a movie so that the film is watched. Indonesian movies from 1970-1990 tended to contain imaginative or artificial social realities. Why? 
Without realizing it, the taste of movie of Indonesian people was formed with action, comedy and sex genres at that time. Movies made with factual messages are actually considered serious movies, which are not entertaining. Cinema movies are interpreted by the audience as mere entertainment tools, not to the level of learning or education.

\subsection{Box Office Movies in the 2000-2010 Period}

The fall of the New Order Government in 1998 followed by a political situation that tended to be democratic, also gave a fresh breeze to movie creativity in Indonesia. Various genres and content of messages were produced, but strangely, the movies favored by Indonesian audiences from 2000-2010 were actually movies with a romantic teen drama genre. According to Bintang tabloid records $(2 / 14 / 2012)$ [8] there were 10 romantic movies favored by audiences during this period, namely: (1) Eiffel I'm In Love (2003, directed by Nasri Cheppy), (2) Romeo \& Juliet (2009, directed by Andibachtiar Yusuf), (3) 3 Hearts, 2 Worlds, 1 Love (Directed by Benny Setiawan), (4) Ayat-ayat Cinta (2008, directed by Hanung Bramantyo), (5) Heart (2006 , directed by Hanny R. Saputra), (6) Days for Amanda (2010, directed by Angga Dwimas Sasongko), (7) Cin(T) a (2009, directed by Sammaria Simanjuntak), (8) LoVe (2008, directed by Kabir Bhatia) , (9) Claudia | Jasmine (2008, directed by Awi Suryadi) and (10) What's with Love? (2002, directed by Rudi Sudjarwo).

From box office movies in 2000-2010, there was a scene of consuming liquor in a movie, Eiffel I'm in Love (2003), which was done by a teenager in a coffee shop or maybe a discotheque. The actor stated that alcoholic drinks are used to celebrate the formation of a gang or squad called Sweet Heart. There is one more scene of drinking liquor used to entertain an upset heart because she was pregnant due to being raped by her own friend [22].

\subsection{Indonesian Box Office Movie in 2010-2017 Period}

In this section, researchers observe Indonesian box office movies per year to find scenes of liquor consumption.

Starting from 2011, there are 10 best-selling movies, namely; (1) Surat Kecil untuk Tuhan (directed by Haris Nizam), (2) Arwah Goyang Kerawang, (3) Get Married 3, (4)? (Question Mark), (5) Pocong juga Pocong, (6) Di Bawah Lindungan Kabah, (7) Purple Love, (8) Tendangan dari Langit, (9) Catatan Si Boy and (10) Kuntilanak Kesurupan. (Hot.detik.com, 12/25/2011) [23].

Arwah Goyang Kerawang, liquor is found on the table at a discotheque. A scene appears where a man is alone with a woman, whose sight invites intimate relationships. The function of beer here is a reinforcement of the impression that liquor is synonymous with sex.
Referring to the Kumparan.com portal (03/03/30), there are 9 best-selling Indonesian movies in the last 10 years, namely: DKI Warkop Reborn: Jangkrik Bos! (2016), Laskar Penagi (2008), Habibie \& Ainun (2012), Ada Apa dengan Cinta 2 (2016), Ayat-Ayat Cinta (2008), My Stupid Boss (2016), Ada Apa dengan Cinta (2002), Cek Toko Sebelah (2016), Eiffel I'm in Love (2003).

From all of the movies above, there are no significant liquor scenes, but in some movies that were less attractive to the audience, there are several scenes about liquor. In the Ayat-Ayat Cinta 2 (2017) movie, a scene of consuming liquor was carried out by Jeong Hwa's family in order to celebrate the success of their business. Jeong Hwa's father offered him a drink, but Hwa stated, "Sorry, I don't drink alcohol!" Liquor consuming scenes are used to reinforce the character of a Muslim who is strong in faith, more specifically not consuming alcoholic beverages.

Now, we analyze the latest developments in Indonesian movies (2018). According to id.mybookmyshow.com (04/04/2012), ten best-selling Indonesian movies in 2018 (until August 2018) are: (1) Flight 555, (2) Titisan Setan, (3) London Love Story 3, (4) Bayi Gaib, Bayi Tumbal, Bayi Mati, (5) Temen Tapi Menikah, (6) Benyamin Biang Kerok, (7) Yowis Ben, (8) Eifell I'm in Love, (9) Danur 2: Madah and (10) Dilan 1990

In Benyamin Biang Kerok movie, two liquor scenes are discovered, one at minutes 3:20 describes the atmosphere of a crowd at the Casino (gambling place). During that scene, young girls perform an erotic dance, and the bartender plays with a bottle of liquor as a show. Liquor in this section is the main characteristic of a casino besides erotic dancers. Then at minute 29:10, liquor is also shown at the gambling mafia headquarters.

In 2018, it is difficult to find liquor in Indonesian movies. First, because the general story setting is about the lives of young children at the High School level. The horror genre takes place about family life, and the rest of the comedy genre movies are mostly played by actors previously known as comedians on Television media. In several Jakarta TV stations, the comedians played in the program with the title, Stand Up Comedy. Even some TV stations held auditions to find talented people for the

Table 1: Movie Title that is studied.

\begin{tabular}{|l|l|l|}
\hline No & Title & Genre \\
\hline 1 & Buaya Gile (1974) & Comedy \\
\hline 2 & Manusia 6.000.000 Dolar (1981) & Comedy \\
\hline 3 & Jawara Kidul (1982) & Action \\
\hline 4 & Minakjinggo (1983) & Action \\
\hline 5 & Nafsu Gila (1983) & Drama \\
\hline 6 & Gembong Wulung (1988) & Action \\
\hline 7 & Sengatan Satria Beracun (1988) & Action \\
\hline 8 & Seruling Naga Sakti (1989) & Action \\
\hline 9 & Titisan Si Pitung (1989) & Action \\
\hline 10 & Roda Roda Asmara Sirkuit Sentul (1995) & Drama \\
\hline 11 & Gairah Membara (1998) & Drama \\
\hline
\end{tabular}


Table 2: Liquor as the Complementary Story.

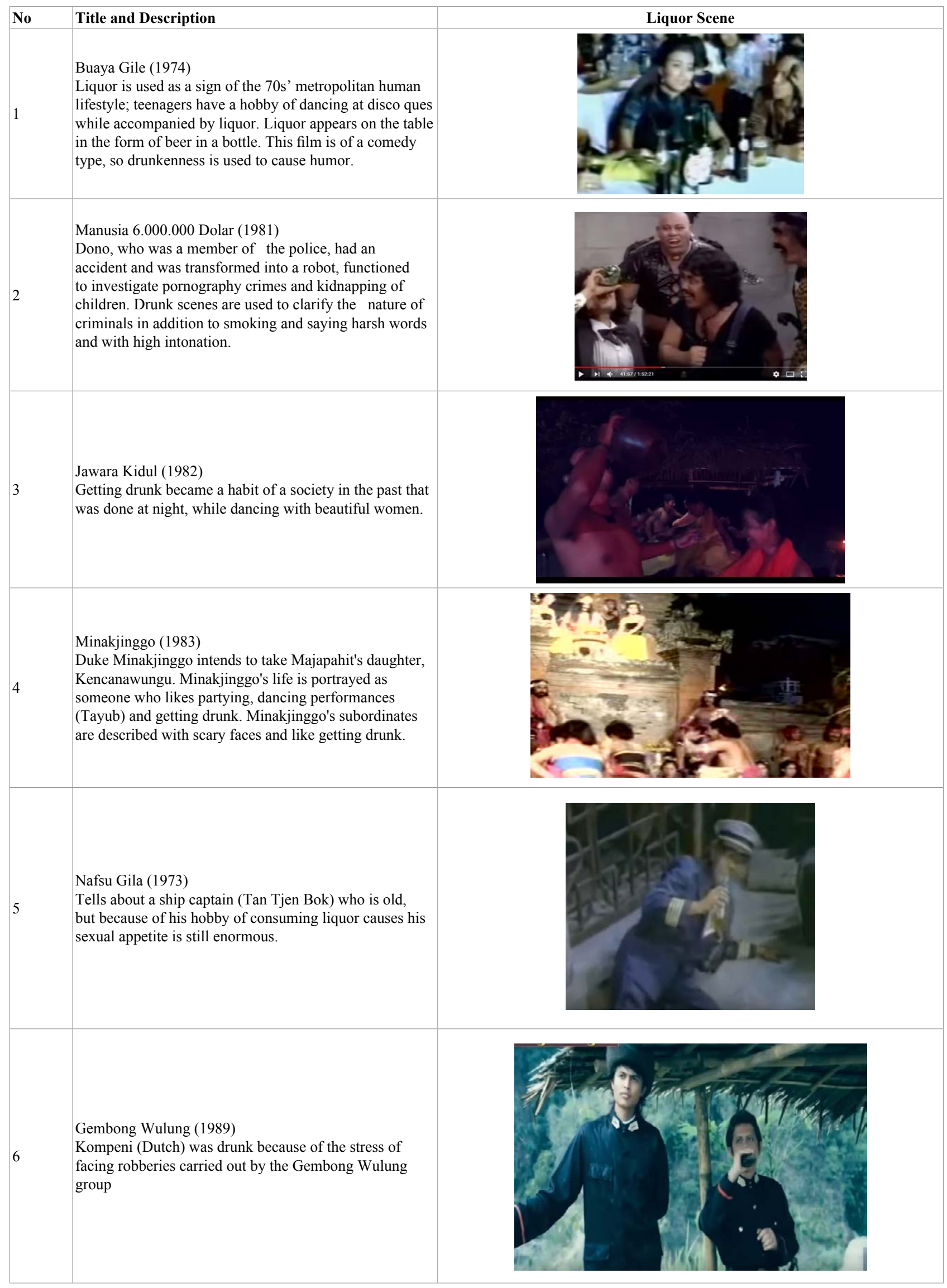




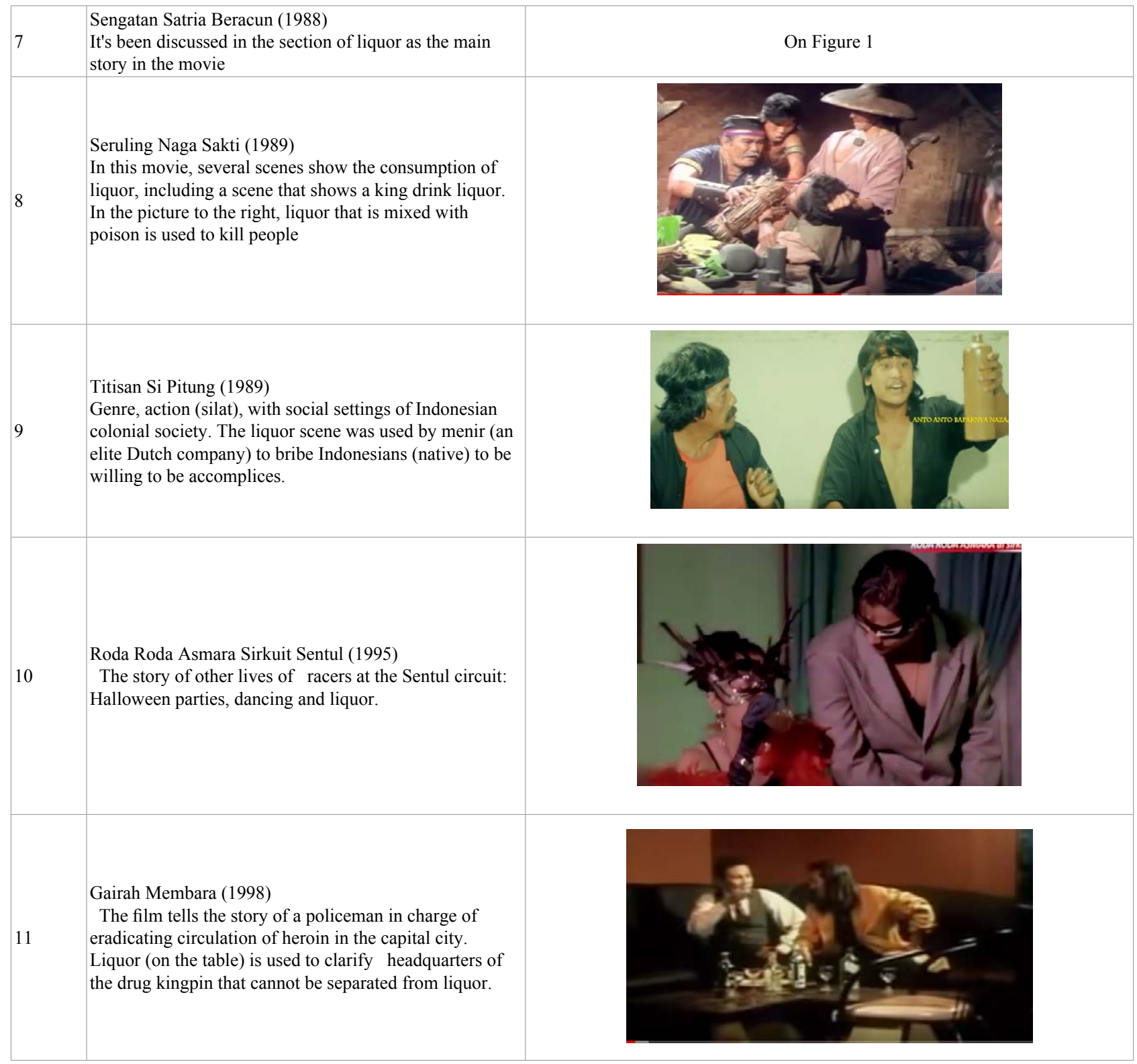

comedy on stage. Therefore, liquor is marginalized in this kind of film genre.

\section{Conclusion}

In the history of Indonesian movies, alcoholic beverages are appointed as stories, both primary and supplementary. In the 1970s, a story about Dewa Tuak appeared in a serial movie, Wirosableng 212, which was based on the novel by Batian Tito. It tells a story about a martial arts teacher who has a habit of consuming alcoholic drinks like Tuak. In this story, the swordsman uses tuak as a medium to generate his magical energy. In the period 1980-1998, many action movies were produced with almost the same model; this tells of life in the time of the Dutch colonial period, the story of warriors who defend the public from the image of natives who are accomplices of Dutch (Kompeni) who enjoy drinking, gambling and cockfighting. After 2000, there were only a few liquor shows in Indonesian movies. Even if there is liquor in a movie, the context is only to give humor as in the Benyamin Biang Kerok movie, or to inflict a horror impression like in the Arwah Goyang Kerawang movie; some shows are even used to portray the refusal of alcoholic beverages like in Ayat Ayat Cinta 2 movie.

The difficulty of alcoholic drinks in Indonesian movies in 2000 and above was also caused by the tendency of the dominant teenage themes, so filmmakers had difficulty linking alcoholic beverages with the developing social reality. With the exception of horror and action-themed movies, alcoholic beverages still appear in a sequel but merely to emphasize an unsafe environment, people who are not good and someone's decision to deal with life's problems where alcoholic drinks are considered as a solution.

\section{Acknowledgement}

This research funding by DRPM Ministry of Research and the Higher Education Republic Indonesia with Grant Number: 005/SP2H/LT/K7/KM/2018. 


\section{References}

[1]. Firmansyah, Bahaya Dan Undang Undang Yang Mengatur Tentang Miras. (2018).

[2]. KOMPAS.Com, Korban Tewas Akibat Miras Oplosan Di Indonesia 112 Orang 2018.

[3]. Liputan6.Com, Tenggak Alkohol Pembersih Luka, 3 Anggota TNI Meninggal Di Puncak Jaya 2018.

[4]. R. Panuju, Sistem Penyiaran Indonesia. Jakarta: Kencana Prenadamedia Group (2017).

[5]. A. Haryanto, The Role of the Global Left Movement in the Fight for Indonesia's Independence (2017).

[6]. E. Maharani, Adegan Pesta Di Film Dorong Kebiasaan Minum Remaja.

[7]. E. Maharani, Adegan Pesta Di Film Dorong Kebiasaan Minum Remaja.

[8]. B. Bintang, 10 Film Indonesia Paling Romantis 2001-2010.

[9]. M. Y. Biran, Sejarah Film 1900-1950 Bikin Film Di Jawa. Jakarta: Komunitas Bambu (2009).

[10]. B. Andersen, Imagined Communities, Komunitas-Komunitas Terbayang. Yogyakarta: Insist Press \& Pustaka Pelajar, 2008.

[11]. S. N. Anggraini, “Aku Yang Galau”: Refleksi Film Masa Kolonial Hingga Awal Kemerdekaan. Jurnal Rekam 11 (2015), 79-93.

[12]. I. Rachmah, Metode Penelitian: Studi Media Dan Kajian Budaya. Jakarta: Kencana Prenadamedia Group.
[13]. I. Di, 10 Film Indonesia Terlaris Di Kuartal Pertama Tahun 2018.

[14]. S. Hall, Representation: Cultural Representations and Signifying Practices. London, Thousand Oaks, New Delhi: Sage (1997).

[15]. N. Ratna (2011) Konsep Diri Remaja Dalam Film Indonesia: Analisis Wacana Atas Film Remaja Indonesia Tahun 1970-2000$A N$. Jurnal Kawistara 1 (2011), 40-55.

[16]. E. N. S. Alkhajar, Masa-Masa Suram Dunia Perfilman Indonesia (Studi Periode 1957-1968 Dan 1992-2000. Surakarta: Pascasarjana Universitas 11 Maret Surakarta.

[17]. Y. V. Wicaksono, Kajian Teori Monuman Beralkohol. Salatiga: Universitas Kristen Satya Wacana.

[18]. A. Cahyono, Potret Kehidupan Pelacur Dalam Film (Studi Semiotika Pada Film Telegram Karya Slamet Rahardjo). Tesis. Malang: Universitas Muhammadiyah Malang (UMM) (2007).

[19]. F. Salesman, The Controversy Between The Indonesian Government Policy And Manggarai's Culture Value About “Sopi” Liquor. J Drug Alcohol Res, 7 (2018).

[20]. F. Nurrahmi, The Narrative Of Identity In The Coverage Of Aceh's Flag. Jurnal Studi Komunikasi, 2(2018).

[21]. R. Panuju, Framing Analysis. Makalah. Surabaya: Universitas Dr Soetomo (2003).

[22]. S. S. Saya, Young Heroes: The Indonesian Family In Politic. New York: Cornel University (2018).

[23]. Hot. Detik.Com. 2011/12/28. 10 Film Indonesia Terlaris 2011. 